\title{
Trace Element Content of Lentinus Squarrusulus Mushroom Collected From Aguata in Anambra State, Nigeria.
}

\author{
Nnorom I. C ${ }^{1}$, Ukaogo O. P $*^{1}$ and Okereke S.C ${ }^{2}$ \\ ${ }^{1}$ Environmental Chemistry Unit, Department of Industrial Chemistry, Abia State University,Abia, Nigeria. \\ ${ }^{2}$ Department of Biochemistry, Abia State University, Uturu, Nigeria.
}

*Corresponding author. E-mail: ukaogoprince@yahoo.com. +2348039466929

\begin{abstract}
The contents of $\mathrm{Cd}, \mathrm{Cr}, \mathrm{Cu}, \mathrm{Fe}, \mathrm{Mg}, \mathrm{Mn}, \mathrm{Mo}, \mathrm{Ni}, \mathrm{Pb}$, and $\mathrm{Zn}$ in fifteen fruiting bodies
Lentinus squarrusulus were determined using Atomic Absorption Spectrometer (AAS). The results showed the values of the studied trace elements decreased in the order: $\mathrm{Zn}\left(63.4-67.6 \mathrm{mg} \mathrm{kg}{ }^{-1}\right)>C d(15.1-18.7 \mathrm{mg} \mathrm{kg}$ $\left.{ }^{1}\right)>M n\left(2.60-4.21 \mathrm{mg} \mathrm{kg}^{-1}\right)>M g(1.57-2.98 \mathrm{mg} \mathrm{kg} \mathrm{l}),>P b(1.21-1.42 \mathrm{mg} \mathrm{kg} \mathrm{l})>\mathrm{Fe}\left(0.40-0.98 \mathrm{mg} \mathrm{kg}^{-1}\right)>C u$ $\left(0.25-0.86 \mathrm{mg} \mathrm{kg}^{-1}\right)>\mathrm{Ni}\left(0.23-0.76 \mathrm{mg} \mathrm{kg}^{-1}\right)>\operatorname{Mo}\left(0.10-0.24 \mathrm{mg} \mathrm{kg}^{-1}\right)>\mathrm{Cr}\left(0.08-0.16 \mathrm{mg} \mathrm{kg}^{-1}\right)$
\end{abstract}

Keywords: Lentinus squarrusulus, Trace element, Atomic Absorption Spectrometer.

\section{Introduction}

In many countries of the world including Nigeria, edible mushrooms have been pricedas delicacies for several years. Apart from their medicinal values, they constitute animportant food source in the world. Mushrooms have been reported to be rich in protein, glycogen, vitamins, crude fibres and essential mineral compounds (Udochukwu et al., 2014).Mushrooms are saprophytes. They include members ofthe Basidiomycota and some members of the Ascomycota. Mushrooms have been a food supplement in various cultures and they are cultivated and eaten for their edibility and delicacy. They fall between the best vegetables and animal protein source. Mushrooms are considered as source of proteins, vitamins, fats, carbohydrates, amino acids and minerals (Adejumo and Awosanya, 2005).Auricularia species have been traditionally used for treating hemorrhoids and various stomach ailments (Chang and Buswell, 1996).However, a plausible assessment of the health risk from mushroom consumption has been difficult, due to very limited knowledge on the chemical form of the metals and their bioavailability in man. Some countries have established statutory limits for the metals in edible mushrooms. Mushroom grows, breaks down and absorbs or mineralizes environmental pollutants into non-toxic form (Hamman, 2004). The presence of heavy metals and other harmful contaminants, which mushroom attacks and digests led to increase in mushroom as opposed to inhibition of mushroom and subsequent removal of toxic metal in the environment by Shiitake mushroom (Hitivani and Mecs, 2003). Mushrooms are generally capable of accumulating trace elements and then become their source in the food chain (maja et al., 2015). Trace elements $\mathrm{Zn}, \mathrm{Cu}, \mathrm{Mn}$ and $\mathrm{Fe}$ are cofactors of enzymes with antioxidant functions and are designated as antioxidant micronutrients(Bhattacharyya et al., 2014). The scavenging of metals from polluted sites by mushroomsare due to remediation and purifying abilities of mushrooms. Emuh (2009) reported that mushroom grows in the presence of heavy metals, secretes enzymesand detoxify such contaminants. Mushrooms are hyper accumulators of heavy metals and radioactive metals thatare toxic to consume and are thus eliminated from the environment. These are bio concentrated in solid forms in the mushroom (Wasser et al., 2003). Lentinula squarrosulusis a wild edible mushroom found in Southeastern Nigeria. It usually grows on damp dead trees and brown in colour. This species has been traditionally eaten by some mushroom fanciers because of its delicious and delicate text. However, little is known about the trace element content in Lentinula squarrosulus. In this study, the contents of nine trace elements in the fruiting bodies of Auricularia auricula- judae from Aguata Area of Anambra State were determined.

\section{Sample preparation}

\section{Materials and methods}

The fully matured fresh fifteen Lentinula squarrosulusismushroom species were collected from different parts of Aguata : Aguluezechukwu, Awka-etiti, Nkpologwu, Achina, Akpo, Isuofia, Ekwulobia, Ikenga, Uga , Igbo-ukwu , Umuchu, Amesi, Ezinifite, Umuona and Oraeri in Anambra State Nigeria, during early raining season in 2015 from fifteen spatially distant sites. The study areas included the farmlands, forests distant from the sources of industrial pollution. The mushrooms were collected at the same developmental stage, and the old or damaged mushrooms were not, also Collections were made at different times of the day: morning, afternoon and sometimes mid-day by uprooting its substratum with the aid of a scalpel and identified by Prof N.B Onyike.Of the Taxonomy Unit of the Department of Plant Science and Biotechnology, Abia state 
University,Uturu. Fresh mushrooms, after removal of plant and substrate debris with a plastic knife, were air dried for several days. They were dried in an oven at $40^{\mathrm{C}}$ for $48 \mathrm{~h}$. Dried samples were homogenized, using an agate homogenizer, and stored in pre-cleaned polyethylene bottles until analysis.

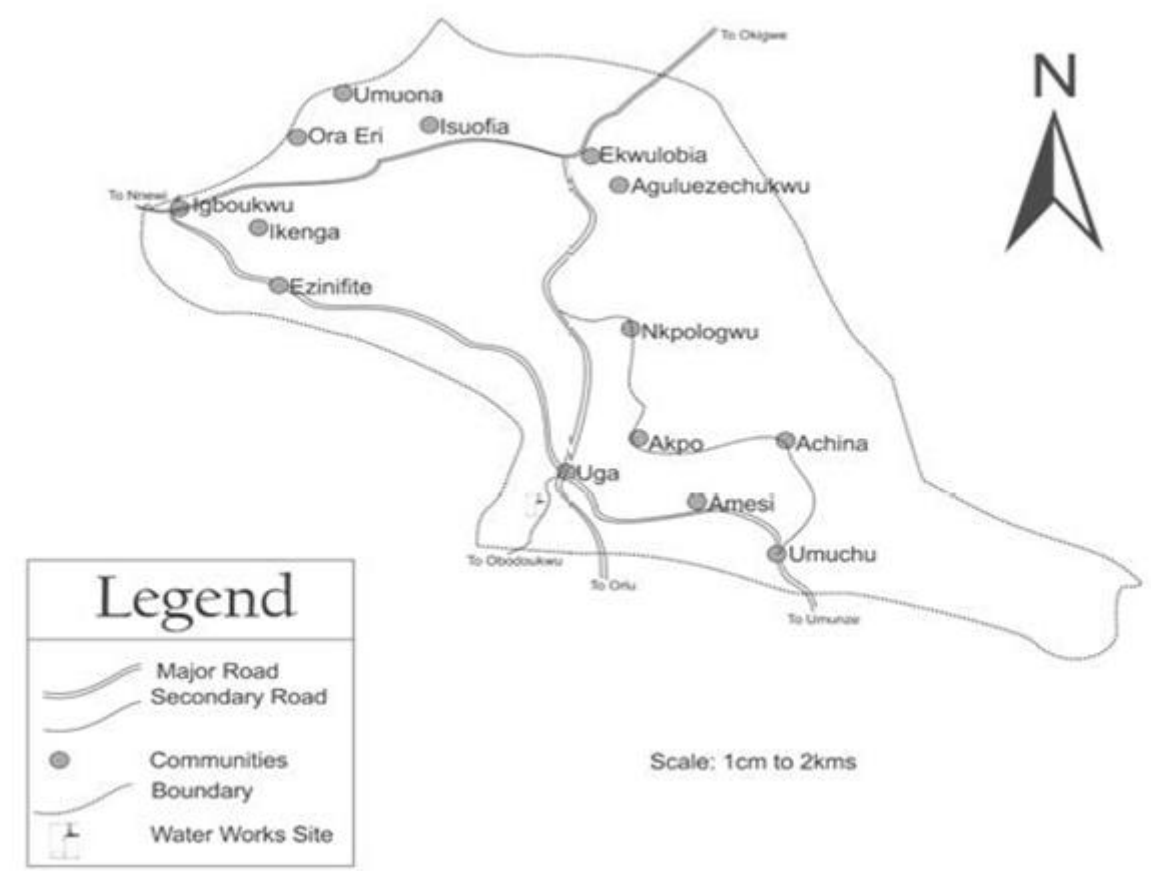

Fig. 1. Localization of the sampling sites (circle) of Lentinus squarrusulus in Aguata, Anambra State.

\section{Analytical methods}

One gramme of sample was placed in a porcelain crucible and ashed at $450^{\mathrm{C}}$ for $18-20 \mathrm{~h}$; then the ash was dissolved in $1 \mathrm{ml}$ concentrated $\mathrm{HNO}_{3}$ (suprapur, Merck), evaporated to dryness, heated again at $450^{\mathrm{C}}$ for 4 h, treated with $1 \mathrm{ml}$ concentrated $\mathrm{H}_{2} \mathrm{SO}_{4}$ (suprapur, Merck), $1 \mathrm{ml} \mathrm{HNO}_{3}$ and $1 \mathrm{ml} \mathrm{H}_{2} \mathrm{O}_{2}$ (suprapur, Merck), and then diluted with double deionized water up to a volume of $10 \mathrm{ml}$. For the element analyses, Atomic Absorption Spectrometer (AAS) was used. $\mathrm{Pb}$ and $\mathrm{Cd}$ levels in the mushroom samples were determined by HGA graphite furnace, using argon as inert gas. Determinations of other heavy metal contents were carried out in an air/acetylene flame. All the experimental results were meansSD of three parallel measurements. Data were evaluated by using one way variance analysis (Stat Most, 1995). The analysis was done at patterns international laboratory Port Harcourt, Nigeria.

\section{Results and discussion}

The trace element contents in the analysed samples are given in Table 1. All element contents were determined on a dry weight basis. The results showed that, among these elements, $\mathrm{Zn}\left(63.4-67.6 \mathrm{mg} \mathrm{kg}^{-1}\right), \mathrm{Cd}^{-1}$ $\left(15.1-18.7 \mathrm{mg} \mathrm{kg}^{-1}\right), \mathrm{Mn}\left(2.60-4.21 \mathrm{mg} \mathrm{kg}^{-1}\right), \mathrm{Mg}(1.57-2.98 \mathrm{mg} \mathrm{kg} \mathrm{1)}, \mathrm{Pb}(1.21-1.42 \mathrm{mg} \mathrm{kg} 1), \mathrm{Fe}(0.40-0.98 \mathrm{mg}$ $\left.\mathrm{kg}^{-1}\right)$

Table 1.Trace element content (mg kg1, dry weight basis) in Lentinus squarrusulus $(\mathrm{n}=15)$.

\begin{tabular}{|c|c|c|c|}
\hline Element & Mean \pm SD & Min & Max \\
\hline $\mathrm{Cd}$ & $16.9 \pm 1.41$ & 15.1 & 18.7 \\
\hline $\mathrm{Cr}$ & $0.12 \pm 0.040 .080 .16$ & & \\
\hline $\mathrm{Cu}$ & $0.55 \pm 0.210 .250 .86$ & & \\
\hline $\mathrm{Fe}$ & $0.75 \pm 0.13$ & 0.400 .98 & \\
\hline $\mathrm{Mg}$ & $2.33 \pm 0.28$ & 1.57 & 2.98 \\
\hline Mo & $0.14 \pm 0.040 .100 .24$ & & \\
\hline $\mathrm{Mn}$ & $3.50 \pm 1.022 .604 .21$ & & \\
\hline $\mathrm{Ni}$ & $0.54 \pm 0.320 .230 .76$ & & \\
\hline $\mathrm{Pb}$ & $1.31 \pm 0.33$ & 1.21 & 1.42 \\
\hline $\mathrm{Zn}$ & $65.4 \pm 1.51$ & 63.4 & 67.6 \\
\hline
\end{tabular}


,Cu (0.25-0.86 $\left.\mathrm{mg} \mathrm{kg}^{-1}\right)$,Ni (0.23-0.76 $\left.\mathrm{mg} \mathrm{kg}^{-1}\right)$, Mo (0.10-0.24 $\left.\mathrm{mg} \mathrm{kg}^{-1}\right), \mathrm{Cr}\left(0.08-0.16 \mathrm{mg} \mathrm{kg}^{-1}\right)$ were found to have the lowest content.Cadmium values in L. squarrusulus sample have been reported to be $3.37 \mathrm{mg}$ kg-1 (Udochukwu et al., 2014). The lower cadmium values found were $0.027 \mathrm{mg} \mathrm{kg-1}$ (Jonathan et al., 2011). The cadmium contents in our mushroom sample ranges: $15.1-18.7 \mathrm{mg} \mathrm{kg-1}$ are higher than values are ported in the literature.

The chromium contents in our mushroom sample ranges: $0.08-0.16 \mathrm{mg} \mathrm{kg}-1$. The values of chromium found were $0.07 \mathrm{mg} \mathrm{kg}-1$ in L. squarrusulus (Ayodele and Odogbili, 2010) and $0.068 \mathrm{mg} \mathrm{kg}-1$ (Jonathan et al., 2011 ) in the literature, respectively. Chromium levels were found to be higher than those reported in the literature. The lower and higher iron contents in L. squarrusulus samples have been reported to be in the ranges: 0.44-58.25 mg kg- ${ }^{1}$ (Ayodele and Odogbili, 2010; Jonathan et al., 2011; Mallikarjuma et al., 2013; Atri and Guleria, 2013; Ayodele et al., 2013; Udochukwu et al., 2014) and $478 \neg 497$ mg kg-1 (Adejumo and Awosanya, 2005; Edosomwan et al., 2013), respectively. The iron values are in agreement with those reported in the literature.Copper contents in the mushroom samples are usually 20ᄀ100 mg kg-1 (Tao et al., 2011). Copper values in L. squarrusulus samples have been reported to be in the ranges: 0.56-2.01mg kg-1 (Ayodele and Odogbili, 2010; Jonathan et al., 2011; Ayodele et al., 2013; Udochukwu et al., 2014), which are higher than that found in this study.

Magnesium values found were $7.21 \mathrm{mg} \mathrm{kg-1}$ in L. squarrusulus ( Atri and Guleria, 2013), $2.94 \mathrm{mg} \mathrm{kg-1}$ (Jonathan et al., 2011) and $21.1 \mathrm{mg} \mathrm{kg-1}$ in (Mallikarjuma et al., 2013). However, the magnesium contents obtained in this study were lower than those reported in the literature.Manganese values in L. squarrusulus samples have been reported to be in the ranges: 0.54- $50.00 \mathrm{mg} \mathrm{kg}-1$ (Adejumo and Awosanya, 2005; Ayodele and Odogbili, 2010; Mallikarjuma et al., 2013; Ayodele et al., 2013). Our manganese values are in agreement with previous studies.Lead values in L. squarrusulus samples have been reported to be $1.25 \mathrm{mg} \mathrm{kg-1}$ (Udochukwu etal., 2014). Our lead values ranges: $1.21-1.42 \mathrm{mg} \mathrm{kg-1}$ are in agreement with those reported in the literature. Molybdenum values in Lentinus squarrusulus samples have been reported in $7.07 \mathrm{mg} \mathrm{kg}-1$ (Atri and Guleria, 2013). These data is higher than the data in this study.Zinc values in samples L. squarrusulus samples have been reported to be in the ranges: 29.3-158 mg kg-1 (Isilogu et al., 2001), 33.5-89.5 mg kg- 1 (Tuzen, 2003), 40.3-64.4 mg kg-1 (Mmendil et al., 2004), 70 mg kg-1 (Edosomwan et al., 2013) and 25.09 mg kg- 1 (Udochukwu et al., 2014). In this study, zinc levels in agreement with those reported in the literature. The lower nickel value $(0.48 \mathrm{mg} \mathrm{kg}$-1) was found in L. squarrusulus (Ayodele and Odogbili, 2010) while the higher nickel value $(2.50 \mathrm{mg} \mathrm{kg}-1)$ was found in (Udochukwu et al., 2014). The nickel values levels 0.23$0.76 \mathrm{mg} \mathrm{kg}-1$ in these study is in agreement with literature values.

\section{Conclusion}

Trace element content of Lentinus squarrusulu collected from Aguata in Anambra State, Nigeria, were determined. The essential elements in this mushroom species were higher than those of toxic elements. The toxic element $(\mathrm{Cd}$, and $\mathrm{Pb})$ contents in this species can be considered sufficiently low and therefore have no health risk.

\section{References}

[1]. Adejumo, T. O. and Awosanya, O. B, (2005). Proximate and mineral composition of four edible mushroom species from South Western Nigeria. African Journal of Biotechnology Vol. 4 (10), pp. 1084- 1088

[2]. Ayodele, S. M., Suleiman, M. N. and Paul, O.(2013) mineral contents and their relative distribution in three edible mushrooms in north central nigeria. niger. j. mycol. vol.5, 27-37

[3]. S. M. Ayodele. S.M and . Odogbili. O.D (2010) Metal impurities in three edible mushroomscollected in Abraka, Delta State, Nigeria. Micología Aplicada International, vol. 22, pp. 27-30

[4]. Atri N.S And Guleria L(2013). Evaluation Of Vitamin, Phytohormone And Trace Element Requirements Of Lentinus Cladopus Lév. International Journal of Pharmacy and Pharmaceutical Sciences 4: 0975-1491

[5]. Bhattacharyya, A.; Chattopadhyay, R.; Mitra, S.; Crowe, S.E. Oxidative stress (2014): An essential factor in the pathogenesis of gastrointestinal mucosal diseases. Physiol. Rev. 2014, 94, 329-354.

[6]. Chang ST and Buswell JA (1996). Mushroom Nutriceuticals. World J. Microbiol. Biotechnol. Vol.12: 473-476. Rapid Science publishers 1996.

[7]. Edosomwan E.U, Akpaja E.O and Iyoha D(2013).Analysis of Bacteria, Helminthseggs andHeavy Metals in Tropical Mushrooms Sold in Selected Markets in Benin City, Nigeria.Botany Research International 6 (1): 17-22

[8]. Emuh, F.N. (2009). Bioremediation Potentials of White Rot Fungi in the Reclamation of crudeoil Polluted Soil. Ph.D. Thesis submitted to Graduate School, Delta State University, Abraka, Nigeria, $180 \mathrm{pp}$.

[9]. Hamman, S. 2004. Bioremediation capability of white rot fungi. B- 1570, Review Article, Spring 2004.

[10]. Hitivani, N., Mecs, L. (2003). Effects of certain heavy metals, on the growth, dye decolouration and enzyme activity of Lentinula edodes. Ectoxicol. Environ. Safety, 55(2): 199203

[11]. Hüseyin Gençcelep, Yusuf Uzun, Yusuf Tunçtürk and Kenan Demirel (2009). Determination of mineral contents of wild-grown edible mushrooms. Food Chemistry 113. Pp 1033-1036

[12]. Isilogu, M., F. Yilmaz and M. Meridivan (2001). Concentration of trace elements in wild ediblemushrooms. Food Chemistry, 73 : 169-175. 
[13]. Jonathan S. G, Amos-Tautua B. M. W and Olawuyi O. J.(2011). Food values, heavy metal accumulation, aflatoxin contamination and detection of exo-polysaccharrides in Lentinus Squarrosulus Berk, a Nigerian mushroom. African Journal of Agricultural Research Vol. 6(13), pp. 3007-3012

[14]. Maja Kozarski, Anita Klaus, Dragica Jakovljevic , Nina Todorovic , Jovana Vunduk ,Predrag Petrović , Miomir Niksic , Miroslav M. Vrvic and Leo van Griensven (2015): Antioxidants of Edible Mushrooms, Molecules . pp 19489-19525

[15]. Mendil, D., O.D. Uluozlu and E. Hasclemir, (2004). Determination of trace elements on some wild edible mushroom samples from Kastamonu, Turkey. Food Chemistry, 88: 281-285.

[16]. S. E. Mallikarjuna, A. Ranjini, Devendra J. Haware, M. R. Vijayalakshmi, M. N. Shashirekha, and S. Rajarathnam(2013). Mineral Composition of Four Edible Mushrooms.Journal of Chemistry.p 5

[17]. Tao Li, Yuanzhong Wang, Ji Zhang, Yanli Zhao, Honggao Liu (2011).Trace element content of Boletus tomentipes mushroom collected from Yunnan, China. Food Chemistry 127: 1828-1830

[18]. Tuzen, M., 2003. Determination of heavy metals in soil, mushroom and plant samples by atomic absorption spectrometry. Microbiological Journal vol. 74, no. 3, pp. 289-297

[19]. Udochukwu, B.O Nekpen, O.C.Udinyiwe and F.I. Omeje (2014). Bioaccumulation of Heavy metals and pollutants by edible mushroom collected from Iselu market Benin-city. Int.J.Curr.Microbiol.App.Sci. 3(10) $52-57$

[20]. Wasser, S., Berreckand, M. Haselwandler, K. 2003. Radiocesium contaminants of wild growing mushroom in Ukraine. Int. J. Med. Mushrooms, 5: 6186. 